\title{
CHANGING OF THE GUARD? AN ANATOMY OF POWER WITHIN SWAPO OF NAMIBIA
}

\author{
HENNING MELBER, DANIELA KROMREy AND MARTIN WElZ*
}

\begin{abstract}
This article presents an anatomy of power relations and policy making within the ranks of the former liberation movement SWAPO in Namibia. It summarizes the features of Namibia's dominant party state and argues that Namibia is a case of competitive authoritarian rule. Our analysis documents how the first generation of SWAPO activists, in exile since the early 1960s, has since independence in 1990 remained the most influential segment of the former anticolonial movement. This continuity is personified in the country's third president Hage Geingob and parts of his team in cabinet. Despite some gradual and increasingly visible shifts in the composition of SWAPO MPs, the party's first generation has so far remained largely in control over the country's political affairs. Analysing the background of the ministers serving since independence also shows, that a second generation of SWAPO activists in exile since the mid-1970s gradually expanded influence and took over leading positions. Given the dominance of SWAPO and the lack of any meaningful political opposition, a new leadership depends on upward inner-party mobility. Given the limited scope for a younger generation to move into higher offices, the strengthening of democracy through new leadership and innovative thinking is very limited. Rather, politics tends to be reproduced through established networks and bonds with a low degree of permissiveness, which reinforces the nature of the competitive authoritarian regime under the control of 'old men'.
\end{abstract}

ANTI-COLONIAL LIBERATION MOVEMENTS IN SOUTHERN AFRICA tend to remain in government for a long time as indicated by the cases of Angola (MPLA since 1974), Mozambique (Frelimo since 1975), Zimbabwe (ZANU since 1980), Namibia (SWAPO since 1990) and South Africa (ANC since 1994). ${ }^{1}$ President dos Santos in Angola (since 1979) and President Mugabe in Zimbabwe (since 1980) are the longest serving Heads of State on the continent, while the leadership of the other three liberation movements-turned-governments has changed. Transitions of leadership in Mozambique and Namibia were relatively smooth and followed the stipulated term limits for heads of state. In South Africa the transfer of power

\footnotetext{
* Henning Melber (henning.melber@nai.uu.se) is Senior Research Associate of The Nordic Africa Institute in Uppsala, Extraordinary Professor at the Department of Political Sciences/University of Pretoria and the Centre for Africa Studies/University of the Free State in Bloemfontein, and Senior Research Fellow at the Institute for Commonwealth Studies/School for Advanced Study at the University of London. Daniela Kromrey (daniela.kromrey@uni-konstanz.de) is Program Director for Internationalization at the Zukunftskolleg, University of Konstanz. Martin Welz (martin.welz@uni-jena.de) is visiting professor at the Friedrich-SchillerUniversity Jena. This article is the result of a collaboration within the Cluster of Excellence 'Cultural Foundations of Social Integration' promoted by the Deutsche Forschungsgemeinschaft (DFG) at the University of Konstanz, which hosted Henning Melber as a Visiting Scholar at the Institute for Advanced Study in March/April 2015. We gratefully acknowledge this support as well as the helpful comments from two anonymous reviewers and the editors of African Affairs. Daniela Kromrey also acknowledges the support of the Friedrich Ebert Foundation.

${ }^{1}$ For a comparative analysis of what he qualifies as 'party machineries' operating in Namibia, South Africa and Zimbabwe, see Roger Southall, Liberation movements in power: Party and state in southern Africa (James Currey, Woodbridge and UKZN Press, Scottsville 2013).
} 
was less harmonious, with Thabo Mbeki replaced before the end of his second term in office. But despite this variation, all five 'presidential democracies' offer interesting case studies of 'big men' rule ${ }^{2}$ that can add to debates about the 'presidentialization' of politics. ${ }^{3}$ They all offer in varying degrees and with different conclusions insights on the relevance of the partyinternal forces at play and the reproduction of, or deviation from, established networks and inner circles of power. This points to the importance of 'old boy networks' and their degree of homogeneity and continuity, or the effects of internal power struggles and opposing factions in either reproducing or modifying a dominant political establishment anchored at independence within the ranks of the anti-colonial movement. The degree of 'presidentialization' of politics in those settings is thereby largely dependent upon the degree of reproduction of political influence by those who determined first the nature of the movement in exile, and then its transformation into a dominant political party and loyalty to the established party leadership.

The extent to which power has shifted between different generations of political leaders and office holders within these Southern Africa liberation movements and the impact of these processes on democracy remains largely unexplored in a systematic manner. ${ }^{4}$ Namibia is an excellent case for analysing such shifts and their effects. One generation into independence one would assume to see a certain degree of intra-party upward mobility of the younger generation, especially since the ruling South West African People's Organization (SWAPO) is widely perceived to have undergone a successful transition from a liberation movement to a political party. ${ }^{5}$ However, such a change has not taken place yet at the top echelons of political influence and power. At 73 years of age, Hage Geingob has become the third 'old man' directly elected by an overwhelming majority of popular votes in national elections to head the Namibian state for a five-year term. A second term in office seems more likely than not.

Notably, Geingob's political ascendancy did not require any repression or coercion, either inside or outside the party. In contrast to all other southern African countries governed by former liberation movements, there have been no politically motivated killings linked to SWAPO since independence. Internal party power struggles have not turned violent, and competitors were not physically eliminated. Nor have any journalists, civil society or human

\footnotetext{
${ }^{2}$ Oda van Cranenburgh, “"Big Men” rule: Presidential power, regime type and democracy in 30 African countries', Democratization 15, 5 (2008), pp. 952-973.

${ }^{3}$ Paul Chaisty, Nic Cheeseman and Timothy Power, 'Rethinking the "presidentialism debate": Conceptualizing coalition politics in cross-regional perspective', Democratization 21, 1 (2014), pp. 72-94; Gianluca Passarelli (ed.), The presidentialization of political parties: Organizations, institutions and leaders (Palgrave Macmillan, Basingstoke, 2015); Ludger Helms (ed.), Comparative political leadership (Palgrave Macmillan, Basingstoke, 2012).

${ }^{4}$ See for example Nic Cheeseman, Democracy in Africa: Successes, Failures, and the Struggle for Political Reform (Cambridge University Press, New York, 2015).

${ }^{5}$ See the Namibian case study in Sebastian Elischer, Political parties in Africa: Ethnicity and party formation (Cambridge University Press, Cambridge, 2013); Andre du Pisani, The impact of democracy in Namibia: Assessing political, social and economic developments since the dawn of democracy (Centre for Policy Studies, Johannesburg, 2009); Christiaan Keulder, Antonie Nord and Christoph Emminghaus, 'Namibia's emerging political culture', in Christiaan Keulder (ed.), State, society and democracy: A reader in Namibian politics (Gamsberg Macmillan, Windhoek, 2000), pp. 237-263.
} 
rights activists who fulfil watchdog functions been subjected to arrest or other forms of drastic state interference. The regular national elections for parliament and the presidency are recognized as free and fair with few reservations concerning the legitimate outcome. Vote rigging or other manipulations seem not to have had any significant impact. Despite several critical observations, Namibia is ranked as 'free' in the annual Freedom in the World report for $2016 .^{6}$

Just as remarkable as SWAPO's political hegemony is the fact that it remains so unspectacular and relatively unnoticed. As a case study, Namibia is conspicuously absent from many comparative analyses of democracy in Africa. Even the debate on competitive authoritarianism has until now only acknowledged the case at its margins, if at all. Competitive authoritarianism is defined as 'civilian regimes in which formal democratic institutions exist and are widely viewed as the primary means of gaining power, but in which incumbents' abuse of the state places them at a significant advantage vis-à-vis their opponents', and therefore, they are not truly democratic 'because the playing field is heavily skewed'. ${ }^{7}$ Based on such dominance, SWAPO achieves election results even authoritarian regimes could only dream of, and it does so without any physical violence while competing with numerous smaller parties.

Exploring and explaining this phenomenon of unprecedented absolute political dominance in combination with - or rather despite of - the 'generational gap' is at the heart of this article. Our original hypothesis motivating the analysis had been that the 'struggle credentials' of individuals have remained an important if not decisive factor for access to political office and that continuity prevails to a large extent, increasingly taking on features of a gerontocracy. This hypothesis leads us to examine the internal party politics and organizational structure of SWAPO and their impact on the office bearers in higher party and government ranks. As the profiles compiled of all ministers serving since independence confirms, there remains indeed an exceptionally high degree of continuity, which is also documented in the average age of those holding offices.

We first review the party's dominance since independence. It becomes evident that SWAPO's hegemony makes Namibian politics by and large an intra-party affair, and therefore we also summarize the internal dynamics within the party. We then analyse the emergence of the Geingob government and assess the breaks and continuities in the party and government leadership. We do so by systematically scrutinizing and categorizing the profiles of cabinet members since independence in a new and comprehensive empirical compilation, providing data on the composition of all Namibian governments since independence. This shows that a decisive generational shift has not yet taken place, even if the influence of the old guard seems to be diminishing slowly. Our findings lead to a few closing questions which might guide further comparative studies of liberation movements as governments in contemporary southern Africa.

\footnotetext{
${ }^{6}$ <https://freedomhouse.org/report/freedom-world/2016/Namibia> (28 August 2016),

${ }^{7}$ Steven Levitsky and Lucan A. Way, Competitive authoritarianism: Hybrid regimes after the Cold War (Cambridge University Press, Cambridge, 2010), p. 5. See also Steven Levitsky and Lucan A. Way, 'Elections without democracy: The rise of competitive authoritarianism', Journal of Democracy 13, 2 (2002), pp. 51-65.
} 
Given the general dominance of the party as a barely contested, almost exclusive agency for governance in post-independence Namibia, it might be assumed that meaningful democratic participation could only take place within the party. This consideration brings the Namibian case into the vicinity of recent debates concerning competitive authoritarianism. ${ }^{8}$ With reference to Kenya, Mozambique, Zambia and Zimbabwe, Steven Levitsky and Lucan Way have argued:

[t]he most durable party-based regimes are those that are organized around non-material sources of cohesion, such as ideology, ethnicity, or bonds of solidarity rooted in a shared experience of violent struggle. In particular, parties whose origins lie in war, violent anti-colonial struggle, revolution, or counter-insurgency are more likely to survive economic crisis, leadership succession, and opposition challenges without suffering debilitating effects. ${ }^{9}$

Levitsky and Way contend further: 'Revolutionary or liberation struggles also tend to produce a generation of leaders ... that possesses the necessary legitimacy to impose discipline during crises'. Hence 'new ruling parties that emerged from violent struggle, such as SWAPO in Namibia, [...] appear to be more durable'. ${ }^{10}$ For southern Africa it can be said that the existing forms of governance cultivate a specific patriotic history as an integral part of ideological legitimacy. This history is based on a narrative that claims (despite differing realities of negotiated change towards controlled transition) that the former liberation movement and now dominant party achieved victory through the barrel of a gun. ${ }^{11}$ Consistent with such logic, SWAPO deems itself entitled to remain the 'sole and authentic representative of the Namibian people'. ${ }^{12}$

\footnotetext{
${ }^{8}$ Matthijs Bogaards and Sebastian Elischer, 'Competitive authoritarianism in Africa revisited', in Zeitschrift für Vergleichende Politikwissenschaft, 10, 1, special issue 6 (2016), pp. 5-18. Published online 1 October 2015, DOI 10.1007/s12286-015-0257-6 (29 November 2015).

${ }^{9}$ Steven Levitsky and Lucan A. Way, Beyond patronage: Ruling party cohesion and authoritarian stability. Paper prepared for the American Political Science Association Annual Meeting. Washington, DC, 2-5 September 2010, p. 3.

${ }^{10}$ Ibid., pp. 44 and 45 . For a more detailed engagement with their notion of 'competitive authoritarianism' as related to Namibia see Henning Melber, 'Post-liberation democratic authoritarianism: The case of Namibia', Politikon: South African Journal of Political Studies 42, 1 (2015), pp. 45-66.

${ }^{11}$ The notion of 'patriotic history' was popularized by Terence Ranger. See, for example, Terence Ranger, 'Nationalist historiography, patriotic history and the history of the nation: The struggle over the past in Zimbabwe', Journal of Southern African Studies 30, 2 (2004), pp. 215-234. See also Norma Kriger, 'From patriotic memories to 'patriotic history' in Zimbabwe, 1990-2005', Third World Quarterly 27, 6 (2006), pp. 1151-1169; Blessing-Miles Tendi, 'Patriotic history and public intellectuals critical of power', Journal of Southern African Studies 34, 2 (2008), pp. 379-396.

${ }^{12}$ Henning Melber, "Namibia, land of the brave": Selective memories on war and violence within nation building', in Jon Abbink, Mirjam de Bruijn and Klaas van Walraven (eds), Rethinking resistance: Revolt and violence in African history (Brill, Leiden and Boston, 2003), pp. 305-327; Henning Melber, 'Namibia's past in the present: Colonial genocide and liberation struggle in commemorative narratives', South African Historical Journal 54, 1 (2005), pp. 91-111.
} 
Political contestation in such post-colonial regimes tends to display a particular blend of democratic and authoritarian features. These have contributed to recent debates on the nature and character of democracy in these states. ${ }^{13}$ As observed more generally, but also based in part on an analysis of Namibia, '[t]he structural conditions in which African parties strive are still conducive to the survival of nondemocratic norms. ${ }^{14}$

SWAPO can be seen as a classic case of the enduring dominance of parties that are rooted in popular movements and that are working towards socio-political emancipation. Such parties 'continue to be associated with important historical legacies, [...] they are well organized and deeply rooted political movements, and [...] they successfully manage leadership change and succession'. ${ }^{15}$ SWAPO has scored remarkably well in all three categories. It was no minor achievement to transform a liberation movement into a party, one which is still to a large extent dominated by the first generation of the liberation struggle's leadership. This continuity provided a welcome stabilizing factor in the institutionalization of the new state, and it enabled a relatively smooth and unspectacular establishment of a new order which 'balanced the demands of institutional reform with continuity'. ${ }^{16}$ At the same time, however, continuity also promoted complacency along with a pronounced and strongly guarded exclusivity. There emerged a 'more exclusivist mode of autocratic rule, continuing to draw on tropes of liberation, development and democracy, but which increasingly appear perverted'. ${ }^{17}$

Namibia's first democratic elections for a Constituent Assembly took place in November 1989. Since then, parallel elections for a National Assembly and the President have been held every five years. SWAPO won every election with a huge majority. Over the past twenty-five years SWAPO was able to expand its dominance and thus consolidate its power. Table 1 displays the results of the six post-independence elections for SWAPO and its closest contenders: the Democratic Turnhalle Alliance (DTA), the United Democratic Front (UDF), the Congress of Democrats (CoD) founded in 1999, and the Rally for Democracy and Progress (RDP) founded in 2007.

\footnotetext{
${ }^{13}$ Claire Metelits and Stephanie Matti (eds), Democratic contestation on the margins: Regimes in small African countries (Lexington Books, Lanham, Maryland, 2015). For Namibia, see Henning Melber, Understanding Namibia: The trials of independence (Hurst, London and Jacana, Auckland Park, 2014; Oxford University Press, New York, 2015).

${ }^{14}$ Elischer, Political parties, p. 273.

${ }^{15}$ Renske Doorenspleet and Lia Nijzink, 'Why one-party dominance endures in some democracies but not others', in Renske Doorenspleet and Lia Nijzink (eds), One-Party dominance in African democracies (Lynne Rienner, Boulder, CO., 2013), pp. 195-207, p. 202.

${ }^{16}$ Sara Rich Dorman. 'Post-liberation politics in Africa: Examining the political legacy of struggle', Third World Quarterly 27, 6 (2006), pp. 1085-1101, p. 1097.

${ }^{17}$ Ibid., p. 1099.
} 
Table 1. Constituent/Parliamentary Election Results 1989-2014 (for larger parties)

\begin{tabular}{lcccccc}
\hline Party & $\mathbf{1 9 8 9}$ & $\mathbf{1 9 9 4}$ & $\mathbf{1 9 9 9}$ & $\mathbf{2 0 0 4}$ & $\mathbf{2 0 0 9}$ & $\mathbf{2 0 1 4}$ \\
\hline SWAPO & $56.90 \%$ & $73.89 \%$ & $76.15 \%$ & $75.83 \%$ & $74.29 \%$ & $80.01 \%$ \\
DTA & $28.34 \%$ & $20.78 \%$ & $9.48 \%$ & $5.14 \%$ & $3.13 \%$ & $4.80 \%$ \\
UDF & $5.60 \%$ & $2.72 \%$ & $2.93 \%$ & $3.71 \%$ & $2.40 \%$ & $2.12 \%$ \\
CoD & - & - & $9.94 \%$ & $7.27 \%$ & $0.66 \%$ & $0.38 \%$ \\
RDP & - & - & - & - & $11.16 \%$ & $3.51 \%$ \\
\hline
\end{tabular}

Source: Based on official figures released by the Electoral Commission as compiled in 'Celebrating 25 years of democratic elections'. Supplement to the newspapers Republikein, Namibia Sun and Allgemeine Zeitung (Namibia Media Holdings, Windhoek, December 2014), pp. 10-11.

SWAPO also benefits from the weakness of the political opposition, which is diverse and factionalized and thus unable to challenge SWAPO's dominance. Fighting within and between the opposition parties renders the opposition ineffective, hampers its contribution to the democratic process and weakens civil society. ${ }^{18}$ Most opposition parties qualify 'as nicheoriented competitors that make specialized appeals to minority electoral constituencies'. ${ }^{19}$ The DTA receives most votes from the white population and the Herero, and the UDF is almost exclusively supported by the Damara, while other smaller parties are supported mainly by Herero or regional-ethnic strongholds in the North Eastern Kavango or among population groups in the Southern region. Hence, the challenges to SWAPO's rule are by all standards limited. Starting with a total of 31 mandates out of 72 in 1989, the number won by opposition parties declined to 19 in 1994, 17 in 1999 and 2004 and 18 in 2009. Parliamentary seats were increased to 96 seats, of which nine different opposition parties took in total only 19 seats as a result of the 2014 election. ${ }^{20}$

As a result, Namibia's political sphere remains mainly the arena of only one party. Opposition parties hardly ever have any markedly different party programs and base their strategy on regional appeals mobilizing ethnic loyalties in combination with an anti-SWAPO sentiment. Since the Namibian electoral system allocates parliamentary seats on a strictly proportional basis, less than one percent of the votes qualify for a seat in parliament. The main ambition for many of the smaller parties' leadership is therefore to enter parliament and receive a good remuneration. This is documented by the absence of hardly any meaningful parliamentary debates.

\footnotetext{
${ }^{18}$ Henning Melber, 'Governance, political culture and civil society under a civil liberation movement in power: The case of Namibia', in Nuno Vidal (ed.) with Patrick Chabal, Southern Africa: Civil society, politics and donor strategies. Angola and its neighbours (Media XXI, Luanda and Firmamento, Lisbon, 2009), pp. 199-212. ${ }^{19}$ Kenneth F. Greene, 'A resource theory of single-party dominance: The PRI in Mexico', in Matthijs Bogaards and Francoise Boucek (eds), Dominant political parties and democracy: Concepts, measures, cases, and comparisons (Routledge, London and New York, 2010), pp. 155-174, p. 155.

${ }^{20}$ See for full details the official announcement of the election results by the chairperson of the Electoral Commission of Namibia on 1 December 2014. <http://bit.ly/2b9mdbK> (15 May 2015).
} 
The presidential elections held parallel to the parliamentary elections present a similar picture. Regularly challenged by the leaders of the bigger opposition parties, SWAPO's candidate always secured more votes than the party (see table 2). This underlines the highly personalized trust or 'social capital' vested in the party candidate while at the same time reinforcing the intra-party influence and role of the candidate elected with such approval rates. It confirms the assumption that a party candidate elected by such popular vote should actually be able to implement his or her own policy and recruitments to a large extent.

Table 2. Results for SWAPO Candidates in Presidential Elections 1994-2014

\begin{tabular}{lccccc}
\hline Candidate & $\mathbf{1 9 9 4}$ & $\mathbf{1 9 9 9}$ & $\mathbf{2 0 0 4}$ & $\mathbf{2 0 0 9}$ & $\mathbf{2 0 1 4}$ \\
\hline $\begin{array}{l}\text { Nujoma } \\
\text { Pohamba }\end{array}$ & $74.46 \%$ & $76.85 \%$ & - & - & - \\
Geingob & - & - & $76.44 \%$ & $76.42 \%$ & - \\
\hline $\begin{array}{l}\text { Difference from } \\
\text { party result }\end{array}$ & $-0.57 \%$ & $+0.70 \%$ & $+0.61 \%$ & $+1.15 \%$ & $+6.72 \%$ \\
\hline
\end{tabular}

Source: Based on official figures released by the Electoral Commission as compiled in 'Celebrating 25 years of democratic elections', p. 18.

Given the opposition's weakness, SWAPO and its leaders have a lot of political room to manoeuvre. Still, it also needs to create intra-party cohesion. This was initially not always without major clashes and fallouts, visible during the ordinary party congresses held every five years and decisive for electing the party leadership as well as the presidential candidate. SWAPO's decision to change the Namibian Constitution with its two-third majority in parliament for the first time to allow the Head of State and party president Sam Nujoma a third term in office ${ }^{21}$ resulted in 1998/99 in the first break-away party with the formation of the Congress of Democrats (CoD), which for two legislative periods (2000-2010) became the biggest opposition party. A full-fledged internal power struggle over Nujoma's succession as Head of State in 2004 led to a purge of those opposing Hifikepunye Pohamba as Nujoma's declared crown prince. Those ousted subsequently founded the Rally for Democracy and Progress (RDP), the party that replaced the CoD as the official opposition for the period 2010 to 2015 as a result of the elections in 2009.

SWAPO members have some influences over party policy through delegates at party congresses, but usually not enough political influence to challenge their leadership on matters of principle. For instance, encouraged by President Pohamba, delegates at an extraordinary party congress held in 2013 amended the party constitution by stipulating, among other things, a 50/50 representation of women and men in all party organs and structures, including

\footnotetext{
${ }^{21}$ Henning Melber, '"Presidential Indispensability" in Namibia: moving out of office but staying in power?', in Roger Southall and Henning Melber (eds), Legacies of Power. Leadership Change and Former Presidents in African Politics (HSRC Press, Cape Town, and Nordic Africa Institute, Uppsala, 2006), pp. 98-119.
} 
the electoral list. ${ }^{22}$ Once adopted, this gender parity was met with concern by men, and debates began over how the predominantly male leaders would retain positions after the next elections. Several informal efforts to avoid strict implementation of gender equity were ignored despite mounting criticism. ${ }^{23}$ Efforts by delegates at another extraordinary party congress failed to revise the decision, since President Pohamba was unwilling to reverse course. ${ }^{24}$ The idea to increase the number of parliamentary seats was regarded as an opportune solution for solving the conflict. Additional parliamentary seats could avoid further intra-party frictions, since that would allow many of the male cadres with struggle credentials to continue their career as MPs.

In line with such logic, the SWAPO parliamentary majority adopted far-reaching constitutional amendments on 21 August $2014,{ }^{25}$ ignoring the demand for proper nation-wide consultation and amidst strong objections by the opposition. ${ }^{26}$ A civil society alliance articulated a concern that 'several of the proposed changes appear to be an attempt to further centralize power and therefore undermine democracy'. ${ }^{27}$ The constitutional amendments were seen to present a 'worrisome potential of abuse in the two-thirds majority'. ${ }^{28}$ The amendments also yielded further power to an already strong executive president, who has the sole discretion to appoint or dismiss his cabinet and all heads of security organs (police, army and intelligence). In addition, the president can name the governors of the 13 regions, independent of the results of the regional elections. The appointment of regional governors

\footnotetext{
22 'Victory for SWAPO women', The Namibian, 24 June 2013.

<http://www.namibian.com.na/indexx.php?archive_id=111089\&page_type=archive_story_detail\&page $=1>(25$ April 2015); see also Amanda Clayton, 'Namibia at a crossroads: 50/50 and the way forward' (Democracy Report, Special Briefing Report no. 7, Institute for Public Policy Research, Windhoek, 2014).

${ }^{23}$ Mathias Haufiku, 'Politburo to finalise 50/50 methodology... rumblings of discontent audible', New Era, 29 April 2014 <http://www.newera.com.na/2014/04/29/politburo-finalise-5050-methodology-rumblingsdiscontent-audible/> (24 April 2015).

${ }^{24}$ Shinovene Immanuel, 'Pohamba declares no going back on 50/50', The Namibian, 28 April 2014

<http://www.namibian.com.na/indexx.php?archive_id=122676\&page_type=archive_story_detail\&page=2> $(18$ September 2015).

${ }^{25}$ Republic of Namibia, 'Motivation of the Namibian Constitution Third Amendment Bill, 2014 in the National Assembly, July 29, 2014', by Honorable Dr. Albert Kawana, MP, Minister of Presidential Affairs \& AttorneyGeneral; Republic of Namibia, National Assembly, Namibian Constitution Third Amendment Bill (as read a first time), B.9- 2014.

26 'Constitutional amendment passed without adequate public consultation, Namibians say' (News release, Institute for Public Policy Research, Windhoek, 28 October 2014).

${ }^{27}$ Graham Hopwood and Toni Hancox, 'Media Statement' (NANGOF Trust, Windhoek, 30 July 2014). NANGOF is the acronym for Namibia Non-Governmental Organisations Forum, the statement was signed by the executive director of the Institute for Public Policy Research (IPPR) and the director of the Legal Assistance Centre (LAC) as co-chairs of the NANGOF Trust Human Rights and Democracy Sector. For a fundamental critique see also the opinion articles by Dianne Hubbard, 'The constitution: how much consultation is enough?', The Namibian, 19 August 2014

<http://www.namibian.com.na/indexx.php?archive_id=127014\&page_type=archive_story_detail\&page $=2>(25$ April 2015), and the constitutional lawyer Nixon Marcus, 'Constitution changes fail the promise of freedom', The Namibian, 22 August 2014

<http://www.namibian.com.na/indexx.php?archive_id=127173\&page_type=archive_story_detail\&page $=1>(25$ April 2015).

${ }^{28}$ Bill Lindeke, 'Presidential power and performance in Namibia: The first quarter century', in 'Celebrating 25 years of democratic elections', pp. 19-20, p. 20.
} 
by the head of state became a constitutional article. Another amendment was the introduction of the office of a vice president, who (as for all government members) is to be appointed by the president alone.

As a result, a symbolic narrative based on 'struggle credentials' superseded 'considerations of uneven delivery in a number of policy domains, and as such resembles a "founding myth" in terms of which the party and the post-apartheid State share a moral and historical assignation'. ${ }^{29}$ he most important feature in terms of political contestations remains SWAPO intra-party competition for control over the party machinery. Decisions within the party over succession and replacements at higher party levels also have a pivotal impact on issues relating to government and state policies. It has been found that SWAPO's 'relationship with intra-party democracy is complicated at best', ${ }^{30}$ while the 'democratic stock' of SWAPO is considered 'extremely low'. ${ }^{31}$ A comparative analysis of candidate selection for the party lists of South Africa's ANC in the 2004 parliamentary elections and for SWAPO in 2004 demonstrated that SWAPO members and their delegates at their party congress - in sharp contrast to the ANC - 'played second fiddle to a relatively small coterie of party notables, including the powerful party leader'. ${ }^{32}$ The construction of the party list at the 2004 SWAPO congress was bitterly contested and 'deeply undemocratic', leading to the establishment of a new party by the losing group. ${ }^{33}$ Similarly contested was the battle over the succession of the first president in office, who - due to the first amendment to the constitution - was allowed to serve three terms from 1990 until 2005. This set of circumstances demonstrated that 'succession is not democratization'. 34

The 'locus of control' rests within the party factions represented in leadership positions. ${ }^{35}$ To a large extent, it remains unchallenged despite some retirements and falling-outs among different segments of the 'struggle generation' that came to power through the first free elections. This finding, described in detail below, suggests that intra-party upward mobility is very limited. Restrictive gatekeeping implies that political influence remains almost exclusively in the hands of the first generation of SWAPO leaders. They hardly allow for any 'fresh blood'. As a frustrated observer posted on a popular forum of a widely read newspaper:

\footnotetext{
${ }^{29}$ André du Pisani, 'The politics and resource endowment of party dominance in Namibia: The past as the present and the future?', in Nicola de Jager and Pierre du Toit (eds.), Friend or foe? Dominant party systems in southern Africa: Insights from the developing world (UCT Press, Cape Town and United Nations University Press, Tokyo, New York and Paris 2013), pp. 132-148, p. 136.

${ }^{30}$ Elischer, Political parties., p. 136.

${ }^{31}$ Shane Mac Giollabhuí, 'How things fall apart: Candidate selection and the cohesion of dominant parties in South Africa and Namibia', Party Politics 19, 4 (2011), pp. 577-600, p. 594.

${ }^{32}$ Ibid., p. 595.

${ }^{33}$ Ibid.

${ }^{34}$ Levitsky and Way, 'Elections without democracy', p. 59.

${ }^{35}$ Gero Erdmann, Matthias Basedau and Andreas Mehler, 'Conclusion. The research agenda ahead', in Matthias Basedau, Gero Erdmann and Andreas Mehler (eds), Votes, money and violence: Political parties and elections in Sub-Saharan Africa (Nordic Africa Institute, Uppsala, 2007), pp. 276-292, p. 279.
} 
I lived in exile in the mid-70s as a teenager that time. We used to be reminded each time we had morning parades in SWAPO camps that we are the youth and the leaders of tomorrow. We were reminded by the same faces I still see today as leaders after almost 40 years and more in leadership positions. When are they going to loosen, let alone step down from these positions? ? $^{36}$

In the following section, we examine such claims of leadership continuity by assessing more closely what has been dubbed 'Team Hage', in reference to the presidential candidate and subsequently elected President Hage Geingob. In particular, we show how Geingob after securing the position of President elect applied a co-optation strategy. He clearly aimed at reducing intra-party opposition by supporting the marginalized older guard and assigning them parliamentary and cabinet positions, which at the same time served to consolidate his position within the party, thereby preparing for the next round of elections.

\section{The formation of Team Hage}

Although Hage Geingob was also a member of the first struggle generation, his career differs considerably from that of his predecessors, presidents Nujoma and Pohamba. Geingob studied at the Temple University in the United States (1964/65), completed a bachelor's degree at Fordham University (1965-1970) and a master's degree in political science at the New School of Social Research in New York. Later on, he obtained a PhD at the University of Leeds in the United Kingdom (2004). ${ }^{37}$ He worked for the United Nations Council for Namibia in New York (1972-1975) before becoming a high-ranking United Nations official as director of the United Nations Institute for Namibia in Lusaka in 1975. In mid-1989 he returned from exile to head the SWAPO election campaign under the United Nationssupervised elections. He then chaired the elected Constituent Assembly and subsequently became the country's first prime minister, appointed by President Nujoma. In the late 1990s, Geingob orchestrated the campaign that secured Nujoma a third term in office. This was based on the argument that Nujoma was appointed by the Constituent Assembly for his first term in office and hence should be allowed to be re-elected by popular vote yet again. The constitution was accordingly amended, with the two-thirds majority of votes the party had held since 1995.

In 2002 Geingob fell out with Nujoma, allegedly for refusing to initiate a 'president for life' campaign. After being demoted he turned his back on Namibian politics and joined the World Bank's Global Coalition for Africa as executive director in Washington DC. He reappeared in local politics when voted onto the party list as number 40, subsequently joining parliament again in March 2005. He returned to the 'inner circle' when the party congress in November 2007 elected (unopposed) not only Hifikepunye Pohamba as the party's president

\footnotetext{
${ }^{36}$ The Namibian, 14 October 2013.

${ }^{37}$ His supervisor was the late Lionel Cliffe. Part of his thesis (entitled State formation in Namibia: Promoting democracy and good governance) was published in a booklet as Drafting of Namibia's constitution (Trustco, Windhoek, 2006).
} 
and Hage Geingob as the party's vice president. ${ }^{38}$ President Pohamba brought Geingob back into the cabinet as Minister for Trade and Industry in late 2008. ${ }^{39}$

The position of vice president in the party automatically implies nomination as the party's presidential candidate for the next presidential election. The stage was set for his later candidacy when Geingob successfully competed for his re-election at the SWAPO Party Congress of November 2012, together with the party's Secretary General (and Minister for Justice) Pendukeni Iivula-Ithana and the Secretary for Information and Publicity (and Minister of Regional and Local Government, Housing and Rural Development) Jerry Ekandjo. While Iivula-Ithana was the first female candidate nominated as the party's presidential candidate, Geingob became the first candidate who was not from the Northern Namibian Ovambo-speaking regions yet who had ethnic roots in the Damara community. Ekandjo became the first SWAPO candidate who had not been in exile but who had 'only' been a local activist and political prisoner on Robben Island, apartheid South Africa's infamous prison island. To the surprise of all informed observers, Geingob received an absolute majority of 312 votes in the first round, ahead of Jerry Ekandjo (220) and Pendukeni Iivula-Ithana (64). Owing to their candidacy for the party vice-presidency, the other two contestants had abandoned the option for re-election into their high party positions held earlier. As a result, Geingob supporters were now voted into their previously held posts. ${ }^{40}$

In a cabinet reshuffle announced on 4 December 2012, Geingob was reinstated as prime minister, effective immediately. There were also other ministerial adjustments, which translated into significant shifts of power intended to strengthen Geingob's base of support. ${ }^{41}$ This tendency was reinforced by the Central Committee's elections for the party's Politburo on 11 December 2012. Geingob's supporters advanced to the upper levels of the hierarchy. Those who supported the other contenders for the vice-presidency paid by losing votes or even seats. ${ }^{42}$ The ten deputies appointed to the party secretariat by President Pohamba at the end of May 2013 were all affiliated with the so-called 'Team Hage', composed of those who openly supported Geingob's ambitions to become the party's presidential candidate. ${ }^{43}$

\footnotetext{
${ }^{38}$ Christof Maletsky, 'SWAPO gears for new era', The Namibian, 30 November 2007

<http://www.namibian.com.na/indexx.php?archive_id=37707\&page_type=archive_story_detail\&page $=2>(26$ May 2015).

39 'Pohamba's reshuffle shows political assertiveness', Informante, 4 October 2008

<http://www.informante.web.na/node/2271> (25 May 2015).

${ }^{40}$ Selma Shipanga and Shinovene Immanuel, 'Moderates prevail', The Namibian, 3 December 2012

$<$ http://www.namibian.com.na/indexx.php?archive_id=103056\&page_type=archive_story_detail\&page=6> $(25$ April 2015).

${ }^{41}$ Selma Shipanga and Shinovene Immanuel, 'Transition team picked', The Namibian, 5 December 2012

<http://www.namibian.com.na/indexx.php?archive_id=103168\&page_type=archive_story_detail\&page $=1>(25$ April 2015).

${ }^{42}$ Shinovene Immanuel, 'Surprises in SWAPO politburo elections', The Namibian, 12 December 2012

<http://www.namibian.com.na/indexx.php?archive_id=103385\&page_type=archive_story_detail\&page=6> $(25$ April 2015). Notably, among those not re-elected were several protagonists of a younger generation.

${ }^{43}$ Tileni Mongudhi, 'Controversies over SWAPO deputies', The Namibian, 31 May 2013

<http://www.namibian.com.na/indexx.php?archive_id=108572\&page_type=archive_story_detail\&page=7> $(25$ April 2015).
} 
With Geingob at the top of the ticket along with 'Team Hage', significant parts of the old guard maintained their political power. However, the party's Electoral College of late August 2014, ahead of the National Assembly elections in November, led to 'tsunami-like waves' causing shock and dismay within the ranks of the old cadres. ${ }^{44}$ The voting for rank on the party's electoral list came as a total surprise. Among those who did not make it onto the list of 96 candidates were four ministers, five deputy ministers and the speaker of the National Assembly, as well as some other MPs. Several more long-standing MPs trailed at the end of the list, unlikely to make the cut. Accusations of 'de-campaigning' caused unrest and tension; party internal factions were accused of having mobilized against certain candidates, thereby violating party rules. Those seeking to explain the unexpected results speculated that the 'decampaigning' had resulted in various factions voting for rather unknown younger candidates with little profile. This created frustration among some of those in the party establishment who as a consequence felt victimised by not being re-elected. The party's secretary general announced an investigation into the allegations but confirmed that the list was deemed valid. ${ }^{45}$ With the list approved, a generational shift seemed inevitable after the 2014 elections. An independent weekly observed:

There is now a new dispensation in the ruling party, one that is dominated by the young Turks. ... The old guard of SWAPO have a bond of liberating a country and are driven by the liberation agenda that they drove successfully to date. ... With the introduction of new blood, SWAPO now have two visible centres of power at both Government and the party level. While most of the young Turks will now be manning government operations come next year the party's central committee is still controlled by the seasoned campaigners. ${ }^{46}$

There was, however, a limited backup plan for the old cadres to continue their parliamentary careers. The amended constitution entitles the state president to nominate eight additional MPs who have no voting rights but qualify for cabinet appointments. Speculation therefore continued as to who would be offered access to political office once Geingob was elected in November 2014. Many observers thought that the president would have to take a strategic approach to the issues:

Meanwhile the results of the electoral college continued to shock many in and outside party circles, an indication that the dust is yet to settle as many stalwarts ponder life out of government for the first time in 24 years. ... Some Geingob supporters maintain that [he ...], apart from having to form

\footnotetext{
44 'Shock and awe ... as SWAPO releases its parliamentary list', Namibia Today, accessed on the SWAPO Party web site <http://www.swapoparty.org/shock_and_awe.html> (15 September 2014). The article quotes a member of the party's Central Committee as stating 'We do not know what happened this time around.' 45 'SWAPO satisfied with "pot” outcome', New Era, 19 September 2014 <https://www.newera.com.na/2014/09/19/swapo-satisfied-with-pot-outcome/> (19 September 2014).

46 'SWAPO tsunami and the Hage's dilemma', The Villager, 1 September 2014 <http://www.thevillager.com.na/articles/7199/Swapo-Tsunami-and-the-Hage-s-dilemma/> (1 September 2014).
} 
a government with a relatively inexperienced lot, might be forced to use his powers to appoint some of the old guard who did not make it onto his list of eight non-voting National Assembly members. ${ }^{47}$

On 2 February 2015, President-elect Geingob announced the creation of a Presidential Council comprised of the president, his two predecessors, the previous prime ministers and their deputies. As Geingob declared with special reference to Nujoma and Pohamba, this was important for

camaraderie, consultation and the continuity of government policy. It is rare that you find a situation like that in Africa. Honestly, that situation is unique to Namibia. These two icons and stalwarts of the struggle, Nujoma and Hifikepunye Pohamba, have 15 and 10 years of governance experience between them respectively, and will be engaged in advisory roles on the Presidential Council. ${ }^{48}$

That the new government would not do away with the recognition of the old guard was reinforced with the appointment of Nickey Iyambo as Namibia's first vice president. He has served for the last twenty-five years in all cabinets and is the oldest within the first generation still holding office. ${ }^{49}$ The reliance on long serving cadres was also mirrored in the selection of the eight additional MPs:

Among those whose political careers have been revived are the Minister of Home Affairs and Immigration, Pendukeni Iivula-Ithana, and youth minister Jerry Ekandjo, who both contested the Party vice presidency during Swapo's elective congress in 2012 but lost to Geingob. [Geingob] also resuscitated the fading political careers of the Minister of Presidential Affairs Albert Kawana and Hardap governor, Katrina Hanse-Himarwa. "These are all stalwarts of the SWAPO Party. In every democratic process there are winners and losers and therefore there are always casualties. However, people who possess knowledge and expertise accumulated over the years are of great value to government. That is why I am nominating them," he said. ${ }^{50}$

\section{According to one commentator, this choice}

has confirmed talks that [Geingob] is moving towards unifying the party and mending fences with old political foes, while turning his back on friends and allies. The move is allegedly to avoid isolation and finding a way around plans to prevent him from taking over as party president in 2017.

\footnotetext{
47 'We serve SWAPO, says old guard', The Namibian, 2 September 2014

<http://www.namibian.com.na/indexx.php?archive_id=127461\&page_type=archive_story_detail\&page=1> $(26$ April 2015).

${ }^{48}$ Elvis Muraranganda, 'Hage brings back Nujoma', Namibian Sun, 3 February 2015

<http://www.namibiansun.com/politics/hage-brings-back-nujoma.76125> (25 April 2015). Nahas Angula,

Theo-Ben Gurirab, Libertina Amathila and Marco Hausiku were announced as the other members of the Council.

${ }^{49}$ During his career in cabinet he held (in chronological order) between 1990 and 2015 the portfolios for health, local government, mines and energy, agriculture and veteran affairs.

${ }^{50}$ Shinovene Immanuel, 'Geingob era begins', The Namibian, 3 February 2015

<http://www.namibian.com.na/indexx.php?archive_id=133114\&page_type=archive_story_detail\&page=5> $(25$ April 2015).
} 
By his own admission Geingob said he had to bring back party heavyweights who failed to secure parliamentary spots at last year's electoral college, for the sake of unity, balance and peace. ${ }^{51}$

The composition of the new cabinet as announced on 19 March 2015 could be seen as another effort to bring different party factions into the same boat: 'Four new ministries, seven renamed portfolios, a top-heavy executive structure, eleven new faces to Cabinet, careers hanging in the balance and ambitions dashed, characterised President-elect Hage Geingob's surprise announcement' ${ }^{52}$ In particular, the expansion of the second-tier level of deputy ministers from 19 to 32 was most likely motivated by the aim of creating inclusivity. Added to the 28 cabinet members, this brought the number of top government officials to almost 60 percent of all MPs and created an enormous challenge for future state budgets; it meant an estimated increase of $\mathrm{N} \$ 15$ million, or 30 percent, to $\mathrm{N} \$ 65$ million as compared with the previous costs of $\mathrm{N} \$ 50$ million under the Pohamba administration. Such expansion can possibly be regarded as an investment in internal party stability to anchor Geingob's own office in structures that support loyalty rather than dissent, if only by the remuneration offered. ${ }^{53}$ The dilemma the new head of state might face had already been commented upon after the earlier announcement of the Presidential Council:

Hage needs the PC more than SWAPO because he has little options in appointing his Cabinet. For the first time the ruling party has more people in Parliament who do not have a sit [sic] in Swapo's decision making bodies, Central Committee (CC) and the Politburo. It is unusual that the party is represented by people who cannot be held accountable at $\mathrm{CC}$ or who are not part of the decision making entity of the part [sic]. . . [W] can ascertain that in trying to balance matters, building bridges and looking across that bridge, we can safely say the difference between Hage and those who are cautious of him in the party is no more subtle than calling a hyena a springbok just because it rolled in springbok dung. Hyenas roll in the springbok dung to mask their own scent for better hunting. ${ }^{54}$

Those with a similar view took the surprise resignation by party president Pohamba as a confirmation. Amidst controversies over procedure and in a reportedly tense atmosphere, he handed over the party presidency to Hage Geingob at the SWAPO central committee meeting on 18 April 2015, well ahead of the scheduled elections at the next party congress in $2017 .{ }^{55}$

\footnotetext{
${ }^{51}$ Tileni Mongudhi, 'Geingob era begins ... as he makes u-turn', The Namibian, 3 February 2015 <http://www.namibian.com.na/indexx.php?archive_id=133148\&page_type=archive_story_detail\&page=1> $(25$ April 2015).

52 Shinovene Immanuel and Tileni Mongudhi, 'Costly democracy', The Namibian, 20 March 2015

<http://www.namibian.com.na/indexx.php?archive_id=134959\&page_type=archive_story_detail\&page=1> $(25$ April 2015).

${ }^{53}$ Jo-Maré Duddy and Estelle de Bruyn, 'Geingob-span kan dúúr wees’, Die Republikein, 23 March 2015

<http://www.republikein.com.na/regering/geingob-span-kan-d-r-wees.243379> (24 March 2015).

${ }^{54}$ Confidence Musariri, 'Opinion - Geingob's 2017 salvo', Oshili 24, 6 February 2015

$<$ http://www.oshili24.com.na/article.php?sid=328\&title=Opinion-Geingob\%27s\%202017\%20salvo> (25 April 2015).

${ }^{55}$ Tileni Mongudhi, 'Geingob takes charge of SWAPO', The Namibian, 20 April 2015
} 
For the time being, Geingob will also continue to act as party vice president. His alleged plan to appoint a close confidante to this position was denied by members of the party organ, who considered the handing over of power as a kind of intra-party coup d'état. There are no provisions in the party's constitution for such a voluntary transfer of power to a successor appointed by the office incumbent. But being president and vice president of the party at the same time was unforeseen and unprecedented. It created an unexpected 'pole position' for Geingob's re-election as party president at the forthcoming party congress, when the next term in office as head of state will be at the forefront of intra-party competition. The party statutes will make the party president the party's candidate for the next general presidential elections if not yet in the second term as head of state (in which case the vice president elected is the party's presidential candidate).

\section{Changing of the guard?}

These strategic decisions substantiate our claim that a marked generational change has not yet taken place. In fact, the government under Geingob carries on the legacies of the past, albeit to a different degree. In line with an earlier analysis, ${ }^{56}$ we consider the compositions of the cabinet as a significant indicator for the representation of the various generations of party activists. We therefore examined the biographies of all cabinet members since independence to assess their history within SWAPO. In addition, we distinguished between liberation campaigners and various categories of SWAPO activists directly involved in the struggle for independence. The 'campaigners' category includes those who visibly supported state sovereignty but did not actively join the fight to overcome foreign rule by apartheid South Africa. Among the 'directly involved' we classified activists in different categories to better trace generational shifts within the party. We differentiated between members of the first generation of exile activists (who left for mobilization abroad from the early 1960s to the early 1970s), the second-generation exile activists (who left Namibia as part of a mass exodus after Angolan independence in 1974/75 and were in many cases further trained at institutions of higher learning abroad), and a third category of 'internal' activists who remained inside the country and mobilized locally, some of whom were subsequently also incarcerated as political prisoners on Robben Island.

This categorization of all members of cabinet since independence was based on a close reading of their biographies. There were only very few borderline cases without a clear recognizable or attributable record in the liberation struggle. Our findings thus offer systematically aggregated data concerning the backgrounds of SWAPO's political leadership.

Our data demonstrates that an average of 94.8 percent of all cabinet members since independence have been SWAPO activists. Their numbers were the highest under Pohamba,

<http://www.namibian.com.na/indexx.php?archive_id=136031\&page_type=archive_story_detail\&page $=1>(25$ April 2015).

${ }^{56}$ Martin Welz and Daniela Kromrey, 'Legacies of the past: The influence of former freedom fighters and their rhetoric in southern Africa', Politikon: South African Journal of Political Studies, 42, 2 (2015), pp. 255-273. 
while the share of former activists was slightly above 75 percent in Geingob's first cabinet. Although a growing number of first generation activists have retired or died, the numbers have remained overall high.

The timeline presented in figure 1 shows the share of SWAPO activists in cabinet. Whereas the later drop can be explained by the aging of former SWAPO activists, the lower share for the first year calls for a brief explanation. Members in the first cabinets after independence included the highest number of liberation campaigners, mainly German-speaking members of the white community. This can be seen both as a sign of reconciliation as well as a recognition that most politically active white liberation campaigners came from this group.

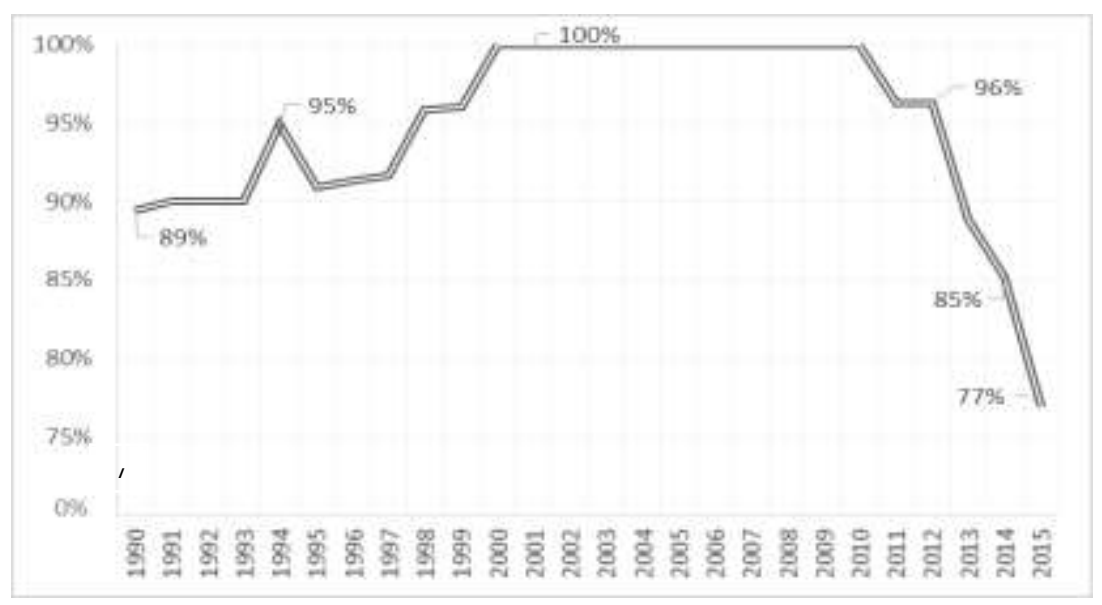

Figure 1. Share of SWAPO activists in Namibia's national cabinets.

Until 2000, SWAPO activists were increasingly recruited to ministerial positions, bringing the percentages of SWAPO activists in the cabinets to a full 100 percent between the years 2000 and 2010. Only in the last years of Pohamba's second presidency did the figures decrease, down to 85 percent in 2014. Geingob's cabinet now incorporates fewer SWAPO activists than ever before. SWAPO activists nonetheless continue to hold three-quarters of all ministerial offices, thereby constituting the majority. Consequently, since these represent the older generations, the average age of the cabinet today is higher than ever. Greater too is its size, with a total of 28 cabinet positions, including ministers, the president, the vice president, the state president and the Director of Intelligence Services.

Taking a more detailed look at the different generations of SWAPO activists reveals some other interesting shifts. As figure 2 shows, the majority of cabinet members were until the early 2000s part of the first generation, but since the inauguration of Pohamba their number decreased. As of 2004 the growing number of second generation and internal activists surpassed the first generation that had been led by Nujoma. This trend became even clearer with Pohamba's second term in office, although surprisingly the number of internal activists 
did not increase much. Today, the second generation has the highest share among the SWAPO activists, even if under Geingob's leadership their total number decreased significantly. This tendency is likely to prevail since the generation of those 'born free' now has voting rights in ever growing numbers and feels less attached to former freedom fighters. Therefore, the old guard and its legitimacy based on former struggle credentials are on the decline.

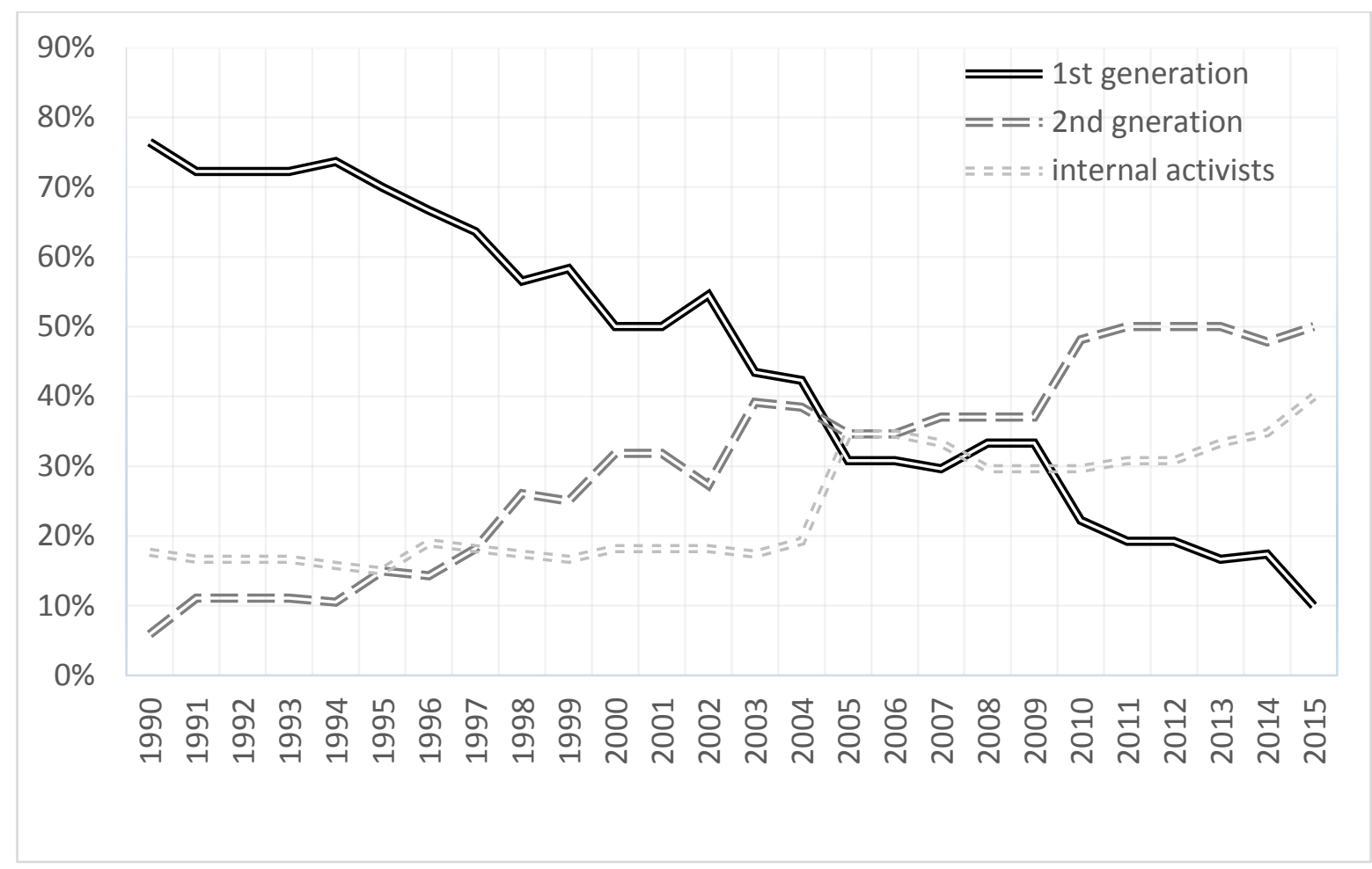

Figure 2. Change of the generations among SWAPO activists.

This does not, however, reduce the high degree of continuity as illustrated in table 3 . The number of cabinet posts filled during the previous six legislative periods adds up to nearly 150, but despite several reshuffles, only 66 persons have occupied ministerial posts thus far, 53 of which have been SWAPO activists. This means that a minister (including the new appointments) spent on average 9.5 years, or close to two legislative periods, in office. If the new appointments of March 2015 are eliminated, the average time in office amounts to almost half of the time during the first twenty-five years since independence and stretches over three legislative periods. 
Table 3. Namibian ministers and their 'struggle credentials' (1990-2015) ${ }^{57}$

\begin{tabular}{|c|c|c|c|c|c|c|c|}
\hline Name & $\begin{array}{c}\text { Year } \\
\text { of } \\
\text { birth }\end{array}$ & $\begin{array}{r}\text { SWAPO } \\
\text { Activist }\end{array}$ & $\begin{array}{l}\text { Liberation } \\
\text { Campaigner }\end{array}$ & $\begin{array}{c}\text { First } \\
\text { generation }\end{array}$ & $\begin{array}{c}\text { Second } \\
\text { generation }\end{array}$ & Internal & $\begin{array}{l}\text { Years in } \\
\text { cabinet }\end{array}$ \\
\hline Alweendo, Tom & 1958 & & $\mathrm{X}$ & & & $\mathrm{X}$ & 5 \\
\hline Amathila, Ben & 1938 & $\mathrm{X}$ & & $\mathrm{X}$ & & $\mathrm{X}$ & 10 \\
\hline Amathila, Libertine & 1940 & $\mathrm{X}$ & & $\mathrm{X}$ & & & 20 \\
\hline Amweelo, Moses & 1952 & $\mathrm{X}$ & & & $\mathrm{X}$ & & 5 \\
\hline Angula, Helmut & 1945 & $\mathrm{X}$ & & $\mathrm{X}$ & & & 19 \\
\hline Angula, Nahas & 1943 & $\mathrm{X}$ & & $\mathrm{X}$ & & & 25 \\
\hline Bessinger, Niko & 1948 & $\mathrm{X}$ & & & & $\mathrm{X}$ & 5 \\
\hline Ekandjo, Jerry & 1947 & $\mathrm{X}$ & & & & $\mathrm{X}$ & 20 \\
\hline Esau, Ben & 1957 & $\mathrm{X}$ & & & & $\mathrm{X}$ & 6 \\
\hline Garoëb, Moses & 1942 & $\mathrm{X}$ & & $\mathrm{x}$ & & & 3 \\
\hline Geingob, Hage & 1941 & $\mathrm{X}$ & & $\mathrm{X}$ & & & 21 \\
\hline Gurirab, Theo-Ben & 1939 & $\mathrm{X}$ & & $\mathrm{X}$ & & & 15 \\
\hline Hamutenya, Hidipo & 1939 & $\mathrm{X}$ & & $\mathrm{X}$ & & & 14 \\
\hline Hanekom, Gert & 1930 & & $\mathrm{X}$ & & & $\mathrm{X}$ & 8 \\
\hline Hangula, Lucas & 1952 & $\mathrm{X}$ & & & $\mathrm{X}$ & & 10 \\
\hline Hanse-Himarwa, Katrina & 1967 & $\mathrm{X}$ & & & & $\mathrm{X}$ & 1 \\
\hline Haufiku, Dr Bernard & 1966 & & $\mathrm{X}$ & & & $\mathrm{X}$ & 1 \\
\hline Hausiku, Marco & 1953 & $\mathrm{X}$ & & & & $\mathrm{X}$ & 25 \\
\hline Herrigel, Otto & 1937 & & $\mathrm{X}$ & & & $\mathrm{X}$ & 2 \\
\hline Herungua, Uahekua & 1969 & $\mathrm{X}$ & $\mathrm{X}$ & & & $\mathrm{X}$ & 2 \\
\hline Iivula-Ithana, Pendukeni & 1952 & $\mathrm{X}$ & & & $\mathrm{X}$ & & 23 \\
\hline Iyambo, Abraham & 1961 & $\mathrm{X}$ & & & $\mathrm{X}$ & & 16 \\
\hline Iyambo, Nickey & 1936 & $\mathrm{X}$ & & $\mathrm{X}$ & & & 26 \\
\hline Jooste, Leon & 1969 & & & & & & 1 \\
\hline Kaapanda, Joel & 1945 & $\mathrm{X}$ & & & $\mathrm{X}$ & & 12 \\
\hline Kameeta, Bishop & 1945 & & $\mathrm{X}$ & & & $\mathrm{X}$ & 1 \\
\hline Kamwi, Richard & 1950 & $\mathrm{X}$ & & & $\mathrm{X}$ & & 10 \\
\hline Kandji-Murangi, Itah & 1961 & & & & & $\mathrm{X}$ & 1 \\
\hline Kandjoze, Obeth & n.a. & & & & & & 1 \\
\hline Kapelwa Kabajani, Richard & 1943 & $\mathrm{X}$ & & $\mathrm{X}$ & & & 10 \\
\hline Kapofi, Frans & n.a. & & & & & & 1 \\
\hline Katali, Isak & 1958 & $\mathrm{X}$ & & & & $\mathrm{X}$ & 5 \\
\hline Katjavivi, Peter & 1941 & $\mathrm{X}$ & & $\mathrm{X}$ & & & 3 \\
\hline
\end{tabular}

\footnotetext{
${ }^{57}$ The list was compiled on the basis of the information in the annually published Africa South of the Sahara (Routledge, New York, various editions) and the cabinet of President Hage Geingob as presented at <http://www.gov.na/cabinet> (17 May 2015). Further information on the categorization of the cabinet members in terms of their political track record was obtained by consulting the entries in Graham Hopwood, Guide to Namibian politics (Namibia Institute for Democracy and Institute for Public Policy Research, Windhoek, 2004) and Graham Hopwood, Guide to Namibian Politics, revised and updated edition (Namibia Institute for Democracy, Windhoek 2007), while the current list of MPs with biographies is accessible at <http://www.parliament.na/index.php?option=com_content\&view=article\&id=234\&Itemid=1179> (24 August 2016). Diverse other information was also secured through a variety of newspaper reports, as well as personal knowledge by Henning Melber, who is a member of SWAPO since 1974. While current MPs were tasked by President Geingob to display their CVs on the web site of the National Assembly within weeks after taking the oath, Obed Kandjoze and Franz Kapofi had not done so by the end of 2015. We therefore could not establish their year of birth.
} 


\begin{tabular}{|c|c|c|c|c|c|c|c|}
\hline Kawana, Albert & 1956 & $\mathrm{X}$ & & & $\mathrm{X}$ & & 13 \\
\hline Kazenambo, Kazenambo & 1963 & $\mathrm{X}$ & & & $\mathrm{X}$ & & 3 \\
\hline Konjore, Willem & 1945 & $\mathrm{X}$ & & & & $\mathrm{X}$ & 5 \\
\hline Kuugongelwa-Amadhila, Saara & 1967 & $\mathrm{X}$ & & & $\mathrm{X}$ & & 13 \\
\hline Malima, Philemon & 1946 & $\mathrm{X}$ & & & $\mathrm{X}$ & & 10 \\
\hline Mbumba, Nangolo & 1941 & $\mathrm{X}$ & & $\mathrm{X}$ & & & 19 \\
\hline Mueshihange, Peter & 1930 & $\mathrm{X}$ & & $\mathrm{X}$ & & & 5 \\
\hline Mungunda, Maria Marlene & 1954 & $\mathrm{X}$ & & & & $\mathrm{X}$ & 6 \\
\hline Mutorwa, John & 1957 & $\mathrm{X}$ & & & & $\mathrm{X}$ & 21 \\
\hline Namoloh, Charles & 1950 & $\mathrm{X}$ & & & $\mathrm{X}$ & & 9 \\
\hline Namwandi, David & 1954 & & & & & $\mathrm{X}$ & 1 \\
\hline Nandi-Ndaitwah, Netumbo & 1952 & $\mathrm{X}$ & & & $\mathrm{X}$ & & 19 \\
\hline !Naruseb, Alpheus & 1954 & $\mathrm{X}$ & & & & $\mathrm{X}$ & 11 \\
\hline Ngatjizeko, Immanuel & 1952 & $\mathrm{X}$ & & & & $\mathrm{X}$ & 11 \\
\hline Nghidinwa, Rosalia & 1952 & $\mathrm{X}$ & & & & $\mathrm{X}$ & 10 \\
\hline Nghimtina, Erkki & 1948 & $\mathrm{X}$ & & & $\mathrm{X}$ & & 18 \\
\hline Nujoma, Sam & 1929 & $\mathrm{X}$ & & $\mathrm{X}$ & & & 15 \\
\hline Nujoma, Utoni & 1952 & $\mathrm{X}$ & & & $\mathrm{X}$ & & 6 \\
\hline Nyamu, Jesaya & 1942 & $\mathrm{X}$ & & $\mathrm{X}$ & & & 6 \\
\hline Pandeni, John & 1950 & $\mathrm{X}$ & & & & $\mathrm{X}$ & 3 \\
\hline Plichta, Hampie & 1934 & & $\mathrm{X}$ & & & $\mathrm{X}$ & 5 \\
\hline Pohamba, Hifikepunye & 1935 & $\mathrm{X}$ & & $\mathrm{X}$ & & & 24 \\
\hline Schlettwein, Calle & 1954 & & $\mathrm{X}$ & & & $\mathrm{X}$ & 3 \\
\hline Shaningwa, Sophia & 1959 & $\mathrm{X}$ & & & $\mathrm{X}$ & & 1 \\
\hline Shifeta, Pohamba & 1968 & $\mathrm{X}$ & & & & $\mathrm{X}$ & 1 \\
\hline Sioka, Doreen & 1960 & $\mathrm{X}$ & & & $\mathrm{X}$ & & 6 \\
\hline Tjiriange, Ngarikutuke & 1943 & $\mathrm{X}$ & & $\mathrm{X}$ & & & 18 \\
\hline Toivo ya Toivo, Andimba & 1924 & $\mathrm{X}$ & & & $\mathrm{X}$ & & 15 \\
\hline Tsheehama, Peter T. & 1941 & $\mathrm{X}$ & & $\mathrm{X}$ & & & 5 \\
\hline Tweya, Tjekero & 1960 & $\mathrm{X}$ & & & & $X$ & 1 \\
\hline von Wietersheim, Anton & 1951 & & $\mathrm{X}$ & & & $\mathrm{X}$ & 2 \\
\hline Witbooi, Hendrik & 1934 & $\mathrm{X}$ & & & & $\mathrm{X}$ & 15 \\
\hline ya Ndakolo, Penda & 1960 & $\mathrm{X}$ & & & $\mathrm{X}$ & & 1 \\
\hline Total & & 53 & 9 & 18 & 18 & 27 & 628 \\
\hline
\end{tabular}

The figures suggest that old cadres with struggle credentials are still in power. Therefore, it would be misleading to diagnose a generational overhaul of the internal power structure of the party, despite the unexpected shifts on the party list for the 2014 elections. As a consequence, 40 of the total 77 elected SWAPO MPs were newcomers. Not all of the newcomers, however, qualified as 'young Turks' in terms of age or party career, for they had been SWAPO activists in other offices or functions (such as regional governors). Rather, those cadres that are actually close to or affiliated with the party's youth wing did not achieve any meaningful impact or success. Overall, the tendencies observed convey increasing features of what could be termed 'generational gatekeeping'. 
Almost all of the candidates promoted towards the end of 2012 by the SWAPO Party Youth League (SPYL), both for the party top positions (such as Jerry Ekandjo as presidential candidate) and the Central Committee, ultimately failed. ${ }^{58}$ Making reference to the expulsion of Julius Malema from the ANC Youth League in South Africa, President Pohamba made it clear in a public speech of 3 March 2012 that his generation, i.e. first generation activists, had steered the liberation struggle and having sacrificed so much, they would not accept criticism from overzealous young Turks who do not recognize the merits of their generation:

It was not easy to fight the liberation war and to liberate Namibia. It was tough and we old people, founder members of SWAPO, had a tough time and I am very much disturbed by those who are insulting SWAPO leaders, such as Sam Nujoma, the man who has sacrificed and had done a lot for the liberation of Namibia and its people. I want to tell you that these old people, have sacrificed their lives for the liberation struggle of Namibia and if you do not respect them, then I want to remind you about what the African National Congress has done with its youth leader Julius Malema and others who wanted to say they are more revolutionary... ${ }^{59}$

Members of the SPYL were criticized on several occasions for their open exchanges and language on Facebook. Such forms of critical debate were considered offensive and disrespectful. A lecture arranged for 5 July 2012 by members of the SPYL 'in their private capacity' for the ousted ANC Youth League leader Julius Malema had to be cancelled for reasons of safety. Or that was at least the tenor of a media statement of 28 June, yet in reality the cancellation was the result of interference by the party's senior leadership. ${ }^{60}$

In a statement dated 29 May 2013, the Youth League leaders claimed that Nujoma agreed with them on their choice of candidates for the party leadership, and they made a scathing attack on Geingob. This provoked the first public endorsement of Geingob by the former President Nujoma in early June. ${ }^{61}$ The SPYL leaders were subsequently taken to task at the Central Committee meeting of 14 June 2013 for their attack on the party's presidential candidate. Several high-ranking party officials called for the SPYL leadership to be dismissed for misbehaviour at the forthcoming extraordinary congress. However, Pohamba

\footnotetext{
${ }^{58}$ Shinovene Immanuel, 'Swapo youth league the biggest loser', The Namibian, 3 December 2012 <http://www.namibian.com.na/indexx.php?archive_id=103054\&page_type=archive_story_detail\&page $=6>(25$ April 2015).

${ }_{59}$ Oswald Shivute, 'Pohamba lashes out at young radicals', The Namibian, 6 March 2012

$<$ http://www.namibian.com.na/indexx.php?archive_id=92543\&page_type=archive_story_detail\&page $=11>(24$ April 2015). The article also adds that Pohamba warned that Malema's fate 'can also happen to those young Namibia leaders, who accuse the elders of being reactionary'.

${ }^{60}$ Shinovene Immanuel, 'SWAPO leaders block disgraced Malema's visit to Namibia', The Namibian, 29 June 2012

<http://www.namibian.com.na/indexx.php?archive_id=96898\&page_type=archive_story_detail\&page $=1>(25$ April 2015).

${ }^{61}$ Kuvee Kangueehi, 'Nujoma endorses SWAPO leadership', The Windhoek Observer, 6 June 2013

<http://www.observer24.com.na/8-latest-news/1612-nujoma-endorses-swapo-leadership> (25 April 2015).
} 
asked for an apology instead of taking disciplinary action. ${ }^{62}$ That apology was officially tendered and confirmed the political defeat of the SPYL whose efforts to gain more influence had ended in humiliation.

Since resuming the highest state office, President Geingob has kept his distance from the youth wing. On 16 May 2015, he decided on very short notice (indeed, hours before the event) not to attend celebrations of former President Nujoma's birthday as organized by the SPYL. The event was intended to promote the so-called 12 May Movement, where the youth wish to have Nujoma's birthday declared a national holiday. According to party insiders, 'the president did not just ditch the event, but also the SWAPO Party Youth League leadership, with whom he still has a strained relationship. ${ }^{63}$ This tense relationship finally resulted in the expulsion of four leading SPYL officials, including its secretary general, in July $2015 .^{64}$ Thereafter the four challenged the decision in court on the grounds of procedure. ${ }^{65}$ The Namibian High Court heard the case in February 2016 and ruled subsequently in April that the party did violate its own procedures. The judge ordered that the expulsion had to be revoked, though the claimants were not entitled to be re-instated into the party positions they had held. ${ }^{66}$ SWAPO decided not to appeal and complied with the ruling. ${ }^{67}$ But since the return of the four as ordinary party members, senior party officials publicly demanded that they should terminate their membership. In sum, SWAPO's young Turks without struggle credentials are not allowed to actively promote a political programme that deviates from that of the older generation.

\section{Conclusion}

Our findings suggest that a generation into independence the Namibian political establishment still bears to a significant extent the imprint of the first generation of activists which first engaged in the anti-colonial struggle half a century ago. This situation can be partly attributed to the success of SWAPO in anchoring a heroic struggle narrative as national discourse in a sovereign state. This narrative accompanied the successful transition from an anti-colonial movement to a political party, albeit with continuous features of the

\footnotetext{
62 'Pohamba saves SPYL', The Namibian, 24 June 2013

<http://www.namibian.com.na/indexx.php?archive_id=111091\&page_type=archive_story_detail\&page=6> $(25$ April 2015).

63 'Geingob snubs 12 May', Windhoek Observer, 22 May $2015<$ http://www.observer24.com.na/8-latestnews/4531-geingob-snubs-12-may> (25 May 2015).

64 'SWAPO vs SWAPO Party Youth League: Ngurare in the firing line', Insight Namibia, 17 July 2015 <http://insightnamibiamagazine.blogspot.se/2015/07/swapos-politburo-and-ngurares.html> (19 September 2015).

65 'High court to hear Swapo expulsions', New Era, 19 August 2015

<https://www.newera.com.na/2015/08/19/high-court-hear-swapo-expulsions/> (19 September 2015).

${ }^{66}$ Amupanda $v$ Swapo Party of Namibia (A 215/2015) [2016] NAHCMD 126 (22 April 2016)

<http://www.saflii.org/na/cases/NAHCMD/2016/126.pdf> (3 August 2016).

${ }^{67}$ Elvis Muraranganda, 'SWAPO welcomes back expelled quartet', New Era, 12 May 2016

<https://www.newera.com.na/2016/05/12/swapo-welcomes-expelled-quartet/> (28 August 2016).
} 
movement's character and its hierarchical manifestations according to which 'loyalty' is considered loyalty towards those who hold leadership positions. It makes it possible for the first generation of leaders to claim and maintain ultimate ownership and responsibility for the liberation of Namibia.

Subsequently, SWAPO activists of the first and second generation in exile became officials in the Namibian government and administration, while as party functionaries they concurrently managed to preserve the 'struggle image' and their corresponding credentials, thereby entitling them to continuous influence - if not dominance - in both party and government matters. Out of the 23 top government office holders during the first legislative period from 1990 to1995, six have passed away, two left SWAPO to form an opposition party, ${ }^{68}$ and four will serve at the senior cabinet level from 2015 to 2020 . Three of them now occupy the most important offices as state and party president (Hage Geingob), state vice president (Nickey Iyambo) and the party's secretary general (Nangolo Mbumba) ${ }^{69}$ Five more are members of the newly created Presidential Council, while others remain influential members of the party's central committee or politburo. Many more in ministerial offices entered the higher echelons during the late 1990s. In any event, the ship of state continues to be steered by those who represent the first generation.

Such a panorama invites comparisons with other liberation movements as governments, as in Zimbabwe, South Africa, Eritrea, Angola and Mozambique. It is likely that there are some similar patterns of 'corporate clientelism' based on political patronage within an inner circle as in other cases of 'big men rule'. Leaders of liberation movements often have generational issues to consider when they become governments, and power relations amongst groups of peers or elders form an important part of the party political setting in which they operate. Once positioned inside the inner power circle, party and government officials all too often resume the role of gatekeepers in both politics as well as the economy. ${ }^{70}$

The case of SWAPO indicates that a liberation movement in hegemonic control over government and administration might rely to a large extent on comradely bonds, which produce a lasting continuity. The lack of political contestation in a society, which despite democratic rules and principles fails to produce any meaningful political opposition, might play a role in the reproduction of old networks within the dominant party. It accordingly limits upward mobility while predisposing the party to gerontocracy. It also seems to limit the scope for inducing changes even by a strong president of party and state. The party

\footnotetext{
${ }^{68}$ The most prominent dissenter, Hidipo Hamutenya, formed and headed the RDP in 2007, but abandoned the opposition party and returned to the SWAPO family at the end of August 2015. As he declared: 'SWAPO is once again the all-inclusive party it used to be, where a spirit of unity and comradeship prevails'. Quoted in 'Teary-eyed Hamutenya blames Swapo exit on "lies", New Era, 28 August 2015

<https://www.newera.com.na/2015/08/28/teary-eyed-hamutenya-blames-swapo-exit-lies/> (19 September 2015).

${ }^{69}$ The fourth is Pendukeni Iivula-Ithana. See 'Namibia's first cabinet: Where are they now?', Namibian Sun, 19 September 2013

<http://www.namibiansun.com/government/namibias-first-cabinet-where-are-they-now.57520> (25 April 2015).

${ }^{70}$ See Tom Lodge, 'Neo-patrimonial politics in the ANC', African Affairs 113, 450 (2014), pp. 1-23; Alexander Beresford, 'Power, patronage, and gatekeeper politics in South Africa', African Affairs 114, 455 (2015), pp. 226-248.
} 
machinery is not at the president's exclusive disposal but permeated by long-standing and deeply rooted obligations and entitlements. Other cases of succession offer sufficient evidence for further comparative studies, contrasting the 'big man syndrome' of the Lider Máximo with the influence of an old guard exercising control and possessing leverage. A particular case in point is the transfer of presidential power from Thabo Mbeki via Kgalema Motlanthe to Jacob Zuma in South Africa and the current ANC-internal positioning over his succession as Head of State. The manoeuvres in Mozambique at the end of the sitting president's two terms in office also involve some important similarities. As in Namibia, the Head of State is elected in Mozambique in direct elections parallel to those for Parliament, while in South Africa the elected government appoints the President. When Armando Guebuza failed to achieve a constitutional change allowing him a third term, the FRELIMOinternal competition for the next presidential candidate to be nominated and elected revealed the continued influence of, among others, former President Joaquim Chissano as well as Graca Machel. ${ }^{71}$ Of course there is also the interesting case of the battle over the succession of Robert Mugabe in Zimbabwe, with shifting scenarios and candidates in what is virtually a "merry go-round" lasting more than a decade. Despite Mugabe's deterioration of health, there exists no clear indication as to who finally will emerge as his replacement. ${ }^{72}$ All these examples may offer additional evidence in seeking to establish the extent to which presidential influence is able to overrule an intra-party circle of an old guard - or vice versa and the extent to which such gatekeeping is a common practice. In many of these cases, as in Namibia and South Africa, a strong executive presidency 'creates intense competition for the presidential nomination, whilst relegating parliamentary candidate selection to an adjunct of this main drama' ${ }^{73}$

As shown in a comparison between ZANU-PF in Zimbabwe and Chama cha Mapinduzi (CCM) in Tanzania,

[t]he 'unity' motif of nationalist struggle disguised and smothered diversity, rather than enabling the emergence of representative national identities and state forms. 'Stability' can mask authoritarianism while 'instability' can provide new leadership, innovative thinking and immense popular support. $^{74}$

\footnotetext{
${ }^{71}$ See Joseph Hanlon, 'Mozambique', in Sebastian Elischer, Rolf Hofmeier, Andreas Mehler and Henning Melber (eds), Africa yearbook: Politics, economy and society south of the Sahara in 2014 (Brill, Leiden, 2015), pp. 457-466, pp. 459-460.

${ }^{72}$ Blessing-Miles Tendi, 'State intelligence and the politics of Zimbabwe's presidential succession', African Affairs 115, 459 (2016), pp. 203-224; Amin Kamete, 'Zimbabwe', in Jon Abbink, Sebastian Elischer, Andreas Mehler and Henning Melber (eds), Africa yearbook: Politics, economy and society south of the Sahara in 2015 (Brill, Leiden, 2016), pp. 505-509; Enocent Msindo, 'Factionalism and Robert Mugabe's leadership on Zimbabwe', in Ebenezer Obadare and Wale Adebanwi (eds), Governance and the crisis of rule in contemporary Africa (Houndmills, Palgrave Macmillan, 2016), pp. 147-172.

${ }^{73}$ Ian Cooper, 'Dominant party cohesion in comparative perspective: Evidence from South Africa and Namibia', Democratization, published online 10 November 2015, DOI: 10.1080/13510347.2015.1099631 (14 November 2015), p. 4.

${ }^{74}$ Greg Cameron and Sara Rich Dorman, 'Problems of nationalism and democracy in Zimbabwe and Tanzania', 2009, p. 15 <http://www.polis.leeds.ac.uk/assets/files/events/democratization-2009/cameron-dorman.pdf> (20 November 2015).
} 
Ordinary people subjected to power politics will often give preference to 'stability', if only to avoid further violent disruption of their daily lives. Zimbabwe's gerontocracy is able to maintain power and influence because of fear among the ordinary people (locally called in Portuguese the povo) that opposition would provoke renewed state terror. They therefore 'will likely opt for social peace and stability, rather than transitional justice or even democratic liberty'. 75

Parties such as SWAPO in Namibia which restrict the growth of opposition and which constrain internal challenges for influence might struggle to generate new leadership and innovative thinking. In fact, competitive authoritarian regimes with a strong presidential democracy rooted in a shared 'struggle history' tend to limit upward mobility within the party and rely on 'old boys networks' (which indeed hardly ever involve women in central positions of power). The absence (or elimination) of any strong opposition parties, which would create political competition and challenges, enhances the reproduction of old bonds. The subsequent absence of avenues for new generations of leaders to emerge under such a constellation in countries like Namibia raises considerable potential problems for the success of democracy in Africa.

\footnotetext{
${ }^{75}$ Michael Bratton, Power Politics in Zimbabwe (UKZN Press, Scottsville, 2014), p. 244; see also Roger Southall, 'History, tyranny, and democracy in Zimbabwe', Africa Spectrum 51, 2 (2016) (in print).
} 